\title{
Seismic Hazard Microzonation Based on Probability Seismic Hazard Analysis in Bandung Basin
}

\section{Anggun Mayang Sari ${ }^{1 *}$ and Afnindar Fakhrurrozi ${ }^{1}$}

${ }^{1}$ Pusat Penelitian Geoteknologi, LIPI, J1. Sangkuriang Bandung 40135

\begin{abstract}
The geological and seismic-tectonic setting in the Bandung Basin area proliferates the seismicity risk. Thus, it is necessary to investigate the seismic hazards caused by the foremost seismic source that affects the ground motions in the bedrock. This research employed Probability Seismic Hazard Analysis (PSHA) method to determine the peak ground acceleration value. It considers the source of the earthquakes in the radius of $500 \mathrm{~km}$ with a return period of 2500 years. The analysis results showed that the Peak Ground Acceleration (PGA) in this region varies from $0.46 \mathrm{~g}$ to $0.70 \mathrm{~g}$. It correlates with the magnitude and hypocentre of the dominant earthquake source of the study locations. The PGA value on the bedrock was used as an input to develop the seismic hazard microzonation map. It was composed using the Geographic Information System (GIS) to visualise the result. This research provides a scientific foundation for constructing residential buildings and infrastructure, particularly as earthquake loads in the building structure design calculations.
\end{abstract}

Keywords: Seismic hazard, PSHA, PGA in the bedrock, GIS, Bandung Basin

$\begin{array}{ll}\text { Naskah masuk } & : 14 \text { Oktober } 2020 \\ \text { Naskah direvisi } & : 7 \text { Desember } 2020 \\ \text { Naskah diterima } & : 8 \text { Desember } 2020\end{array}$

*Penulis korespondensi.

Email: angg021@lipi.go.id;

anggunnmayangsari@gmail.com

\begin{abstract}
ABSTRAK - Mikrozonasi Bahaya Seismik Berdasarkan Probability Seismic Hazard Analysis di Cekungan Bandung. Kondisi geologi dan seismik-tektonik di Cekungan Bandung meningkatkan risiko kegempaan di wilayah tersebut. Oleh karena itu, perlu dilakukan penelitian tentang bahaya seismik yang disebabkan oleh sumber-sumber gempa di sekitarnya yang mempengaruhi gelombang gempa di batuan dasar. Penelitian ini menggunakan metode Probability Seismic Hazard Analysis (PSHA) untuk menentukan nilai percepatan gelombang gempa di batuan dasar. Lebih lanjut penelitian ini menggunakan sumber gempa dalam radius $500 \mathrm{~km}$ dengan periode perulangan 2500 tahun. Hasil analisis menunjukkan bahwa Peak Ground Acceleration (PGA) di wilayah ini bervariasi dari 0,46 g hingga 0,70 g. Hal ini berkorelasi dengan magnitudo dan jarak hiposenter sumber gempa dominan terhadap lokasi penelitian. Nilai PGA di batuan dasar digunakan sebagai input data dalam pembuatan peta mikrozonasi bahaya seismik. Peta mikrozonasi bahaya seismik disusun dan divisualisasikan menggunakan Sistem Informasi Geografis (SIG). Luaran penelitian ini menghasilkan landasan ilmiah pada konstruksi bangunan tempat tinggal dan infrastruktur, khususnya sebagai pembebanan gempa dalam perhitungan desain struktur bangunan.
\end{abstract}

Kata kunci: Bahaya seismik, PSHA, PGA pada batuan dasar, SIG, Cekungan Bandung

\section{INTRODUCTION}

There are two types of earthquake source which geologically affect Bandung Basin; namely the subduction and the shallow crustal zone (Sengara et al., 2001). Lembang Fault is the typical shallow crustal earthquake affecting the basin (Daryono et al., 2019). While the Sunda Megathrust, which is part of the West-Central Java segment, is a typical 
subduction earthquake affecting the basin (Syahbana et al., 2018). These earthquake lines have significant physical impacts on several areas in the Bandung basin, including Bandung Regency, Bandung City, and West Bandung Regency. The Metropolitan area in Greater Bandung consists of 56 districts and has a total built-up area of 26,142 Ha of 106,015 Ha (West Java Province Metropolitan Development Management (WJPMDM), 2013). Hence, scientific information about seismic hazards plays a vital role in earthquake-prone area development, especially in infrastructure and building development.

Several large earthquakes swayed the Bandung basin over the last decade. A prior paleoseismological study has estimated these events based on historical earthquake events. The Lembang Fault triggered an earthquake event with a magnitude around 6.6 Richter scale (R) 2,000 years ago, and this activity has a strong possibility to recur in the future (Yulianto, 2011).

Correspond to this claim, on September 2nd, 2009, the megathrust activity in the south of Java subduction zone triggered a large earthquake event at Tasikmalaya (Daryono et al., 2009). It had a magnitude of 7.3 on the Richter Scale (R), with the epicentre located at -8.24 latitude and 197.32 longitude. The waves rippled through the Bandung basin, which caused considerable losses and severe damages to 53,910 houses and 2,461 public facilities. Moreover, a total of 23 people had died or disappeared, and also, 78,174 people were displaced and suffered.

Two years later, on July 28th and August 28th, there were earthquake events located in Bandung city with a magnitude of 2.9 and 3.3 Mercalli (M), respectively. These events created minor damage to 103 buildings in the Bandung basin (Meilano et al., 2012). The dense population in residential areas in this area is one crucial factor in considering preventive measures to reduce the risk of earthquake events that require an in-depth study of seismic hazards.

Seismic hazard analysis is an approach to estimate the earthquake ground shaking hazard at a particular location. The aim is to advance earthquake-resistant building design and to assess building safety such as bridges, high-rise buildings, dams, etc (Gupta, 2002). There are two conventional approaches to analyse seismic hazard, namely Deterministic Seismic Hazard Analysis (DSHA) and Probability Seismic Hazard Analysis (PSHA) (Krinitzsky, 1995). On the one hand, DSHA is the probability of ground motion analysis using a simple statistic of a single or a set of earthquakes (Krinitzsky, 2002). On the other hand, PSHA considers uncertainties or noncontrolled sources, such as future earthquakes (Baker, 2013). Additionally, the DSHA approach calculates site-specific evaluation, while the PSHA approach considers the recurrences of events. The PSHA approach obtains peak ground acceleration value from ground motion on the bedrock to estimate earthquake event occurrences in 2500 years return period.

Recent studies on seismic hazard analysis in the Bandung Basin have been accomplished. Horizontal-to-Vertical Spectral Ratio (HVSR) approach and site classification from $\mathrm{CPTu}$ and SPT data were used to reveal velocity amplification distribution in the Bandung Basin (Sari et al., 2019). Another study used a different approach that considers seismic sources from subduction areas and active faults surrounding the Bandung Basin (Sengara et al., 2001). It is necessary to research seismic hazard analysis using the latest earthquake sources as the number of installed seismic instruments has been increasing and lead to successful seismic source identification (Tim Pusat Studi Gempa Nasional, 2017). Hence, it is possible to obtain peak ground acceleration close to the real condition using the latest seismic sources and attenuation equations.

An investigation of the earthquake data collected from the year 2009 until 2011 showed that the earthquake disaster was not solely caused by active faults movement located close to the Bandung Basin but also had to consider other earthquake sources. For instance, the PGA value in the bedrock was determined using the seismic hazard analysis approach. Furthermore, this research presents a seismic microzonation map to display the PGA values' distribution from seismic sources with a buffer radius of $500 \mathrm{~km}$ measured from the centre of Bandung Basin.

\section{GEOLOGICAL TECTONIC SETTING}

Bandung Basin was developed by several geological formations, as shown in Figure 1. The youngest formation, Kosambi Formation, consists of Holocene tuffaceous sand, silt, and clay, which 


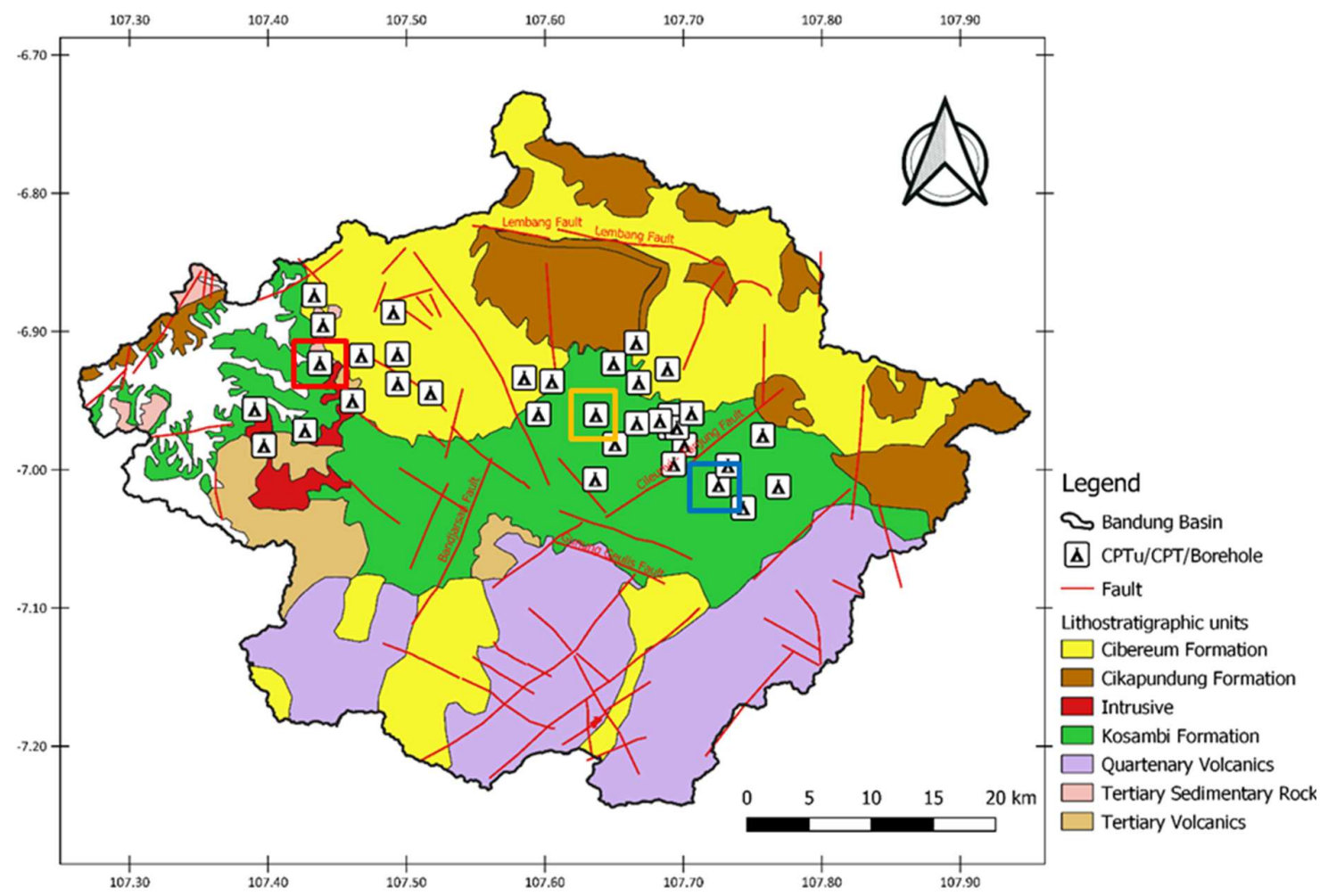

Figure 1. Geological map of the Bandung basin and CPTu/Borehole sampling site locations (geological map was compiled and modified from Sudjatmiko (1973), Koesoemadinata and Hartono (1981), Alzwar et al (1992), Silitonga (2003), Hutasoit (2009), Gumilar (2013). Red box, orange box and blue box show the location of CPTu04, CPTu13 and BH-02 respectively.

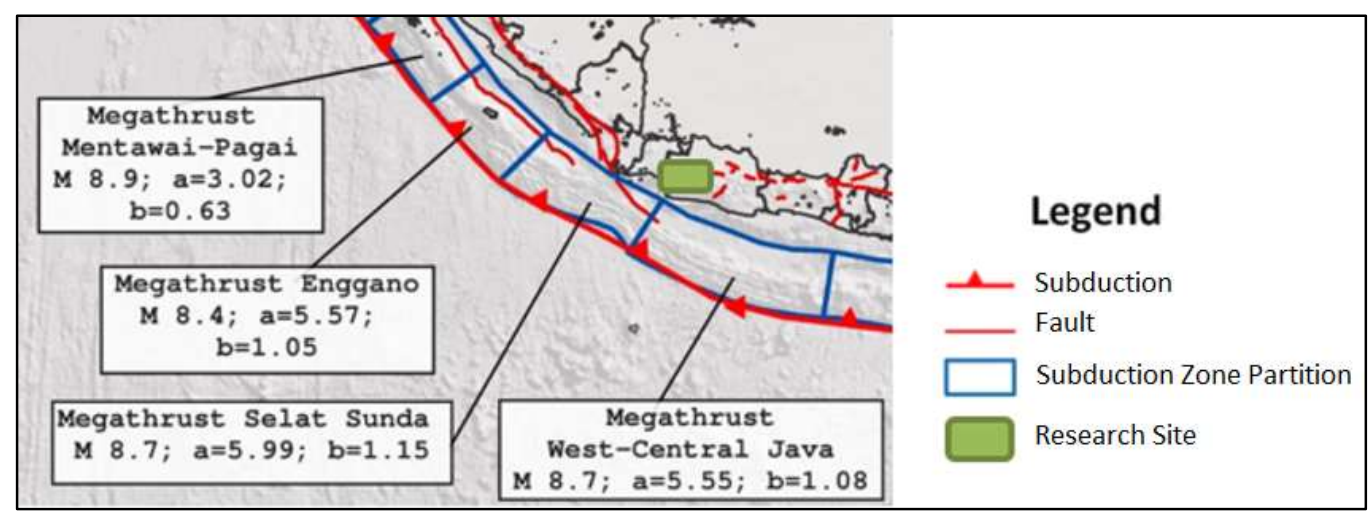

Figure 2. Seismic fault and subduction surrounded West Java, where $M$ is Magnitude, $a$ and $b$ is a Gutenberg-Richter constant value. (modified from Tim Pusat Studi Gempa Nasional (2017)).

presents in the southern part of the Bandung Basin. Cibereum Formation that older than the Kosambi Formation, composed of pumice, obsidian, basalt, breccia, tuff, and andesite. This formation presents in the west to the eastern part of the Bandung Basin. The oldest part, Cikapundung Formation, is exposed in the northern part of Bandung Basin, consisting of 
breccia, lahar, and lava. The Bandung Basin's bedrocks consist of Tertiary sedimentary rocks, Tertiary volcanic rock, and intrusive rocks. These geological rocks outcrop along the northern part of the Bandung Basin, from west to the east (Silitonga, 2003). Based on these geological formations, 35 different samples were collected using Cone Penetration Tests (CPTu) and borehole measurements. They were distributed in 9 locations in Bandung district, 12 locations in Bandung City, and 14 locations in West Bandung Regency. The distribution of sampling site locations is shown in Figure 1. As for the tectonic setting, there is a subduction mechanism that mainly affects the Bandung Basin.

The subduction zone between the Indo-Australian plate beneath the Eurasian plate causes several identified and unidentified active faults (Soehaimi, 2011). For instance, the identified active faults, such as the lateral strike-slip of Lembang Fault, Cimandiri Fault, and the Baribis Fault, are found in West Java. On the contrary, unidentified right-lateral slips located in the Garut cluster might be related to the local fault (Supendi et al., 2018).

The Lembang Fault has a length of approximately $29 \mathrm{~km}$ and a slip-rate of around $1.95-3.45 \mathrm{~mm} / \mathrm{yr}$ (Daryono et al., 2019). While the Cimandiri Fault has $23 \mathrm{~km}$ in length and a slip rate around 0.55 mm/yr (Tim Pusat Studi Gempa Nasional, 2017). Subduction mechanism also has a vital role in seismic hazard impacts in the Bandung Basin, such as the Sunda Strait Megathrust and WestCentral Java Megathrust (Sari et al., 2020), as shown in Figure 2.

\section{METHODOLOGY}

The seismic hazard analysis was accomplished using the PSHA method (Baker, 2013), consisting of uniform hazard spectra calculation, deaggregation, and ground motion synthetic modelling. Furthermore, it also incorporates some uncertainties parameters, namely the earthquake magnitude, the earthquake's location, attenuation of earthquake shocks, and earthquake events' recurrence rate (Tim Pusat Studi Gempa Nasional,

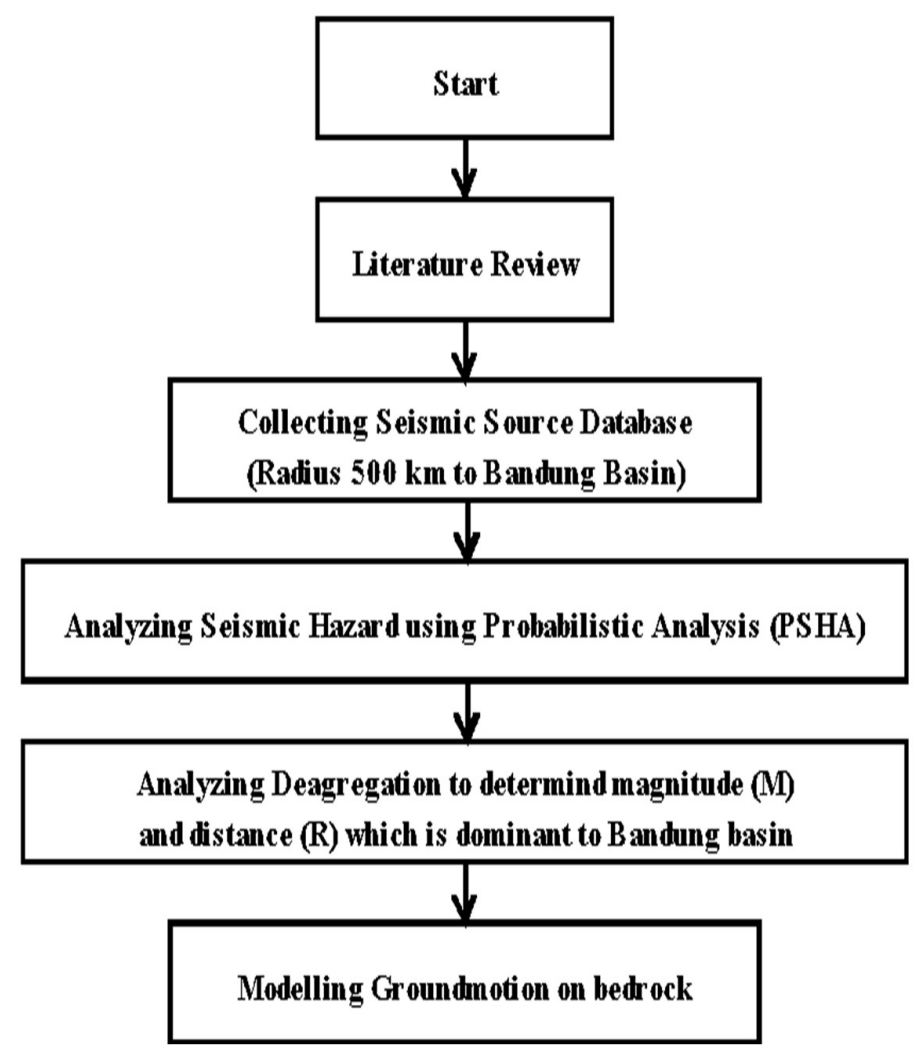

Figure 3. Flow chart of seismic hazard analysis in this study. 
Table 1. Megathrust source database used in PSHA.

\begin{tabular}{|c|c|c|c|c|c|c|}
\hline \multirow{2}{*}{ Structure } & \multirow{2}{*}{ Segment } & \multirow{2}{*}{$\begin{array}{c}\text { Length } \\
(\mathbf{k m})\end{array}$} & \multirow{2}{*}{$\frac{\text { Width }}{(\mathrm{km})}$} & \multirow{2}{*}{$\begin{array}{c}\text { Magnitude } \\
\text { PSHA }\end{array}$} & \multirow{2}{*}{$\mathbf{b}^{*}$} & \multirow{2}{*}{$a^{*}$} \\
\hline & & & & & & \\
\hline Sumatran Megathrust & Selat Sunda & 290 & 100 & 8.7 & 1.15 & 5.99 \\
\hline Sunda Megathrust & West-Central Java' & 700 & 150 & 8.7 & 1.08 & 5.55 \\
\hline Sunda Megathrust & East Java & 280 & 150 & 8.7 & 1.08 & 5.63 \\
\hline
\end{tabular}

${ }^{*}$ Gutenberg-Richter constant value

2017). The main essence of the PSHA method is seismic source identification in the radius of 500 $\mathrm{km}$ from coordinates locations and calculation using selected attenuation functions, such as the Ground Motion Prediction Equation (GMPE). The attenuation function estimates the level of ground shaking due to earthquake waves concerning the magnitude, the distance from the earthquake source to a particular location, and an earthquake source's conditions. The seismic source database was obtained from secondary data. A brief description of the research method is shown in Figure 3.

This study used 29 seismic sources database collected from Peta Sumber dan Bahaya Gempa Indonesia Tahun 2017 (Tim Pusat Studi Gempa Nasional, 2017) and Daryono et al. (2019), as shown in Table 1 and Table 2. PSHA analysis used these seismic sources data as an input database to produce ground motion synthetics on the bedrock.

There are four stages of procedure to obtain PSHA synthetic ground motion. The first stage is to identify the seismic sources mechanism, faults mechanism, subduction mechanism, and select the appropriate attenuation function for each mechanism. The seismic source mechanism opted for GMPE as the attenuation function. The attenuation equation functions used for fault mechanism are the Next Generation Attenuation (NGA) from Boore and Atkinson (2008), Campbell and Bozorgnia (2008), Chiou et al. (2008), and Chiou and Youngs (2008). Meanwhile, the attenuation equation functions for the subduction mechanism applied in this research are Atkinson and Boore (2003), Zhao et al. (2006), and Youngs et al. (1997). The second stage is to determine the seismicity and earthquake distribution on these attenuations function using the logic tree. This logic tree used in PSHA analysis resulted in the Probabilistic Spectra graph. The Probabilistic Spectra graph shows spectral acceleration as a function of the spectral period for a specified return period or equivalently annual probability of exceedance, known as Uniform Hazard Spectra (UHS).

The next step is obtaining the dominant earthquake magnitude and distance, known as deaggregation. Deaggregation determined the most significant earthquake source among many earthquake sources within a $500 \mathrm{~km}$ buffer and based on recurrent earthquake events per year (Sunardi, 2015). These results were used to obtain the response spectra. The modification of response spectra and UHS value were performed to obtain Modified Response Spectra (MRS). The deaggregation also produced the hazard curve. The hazard curve showed a full picture of dominant earthquake sources and mechanisms that influence the particular location.

Finally, ground motion synthetics are developed to determine the seismic hazard. It is based on seismic conditions at a particular area using spectral matching between the MRS against the time histories. In this study, the targeted spectra between PSHA's UHS and deaggregation response spectra were used for the MRS acquisition. Moreover, recorded data of earthquake acceleration merged as the time histories into the MRS. Thus, this spectral matching resulted in ground motion synthetics based on the earthquake source's real conditions affecting the particular location.

\section{RESULT AND DISCUSSION}

The PSHA results are shown as the UHS curves, that resulted in the hazard spectra involving 29 seismic sources to the site location for a return period of 2475 years. These graphics showed a relationship between spectral acceleration and 
Table 2. Faults source database used in the PSHA.

\begin{tabular}{llrrrc}
\hline Segment & $\begin{array}{l}\text { Fault } \\
\text { Type }\end{array}$ & Dip & $\begin{array}{c}\text { Length } \\
\text { (km) }\end{array}$ & $\begin{array}{c}\text { Width } \\
\text { (km) }\end{array}$ & $\begin{array}{c}\text { Magnitude } \\
\text { (Maximum) }\end{array}$ \\
\hline Kumering-North & SS & $\sim 90$ & 111 & 20 & 7.5 \\
Kumering-South & SS & $\sim 90$ & 60 & 20 & 7.1 \\
Semangko Barat-A & SS & $\sim 90$ & 90 & 20 & 7.4 \\
Semangko Barat-B & SS & $\sim 90$ & 80 & 20 & 7.3 \\
Semangko Timur-A & SS & $\sim 90$ & 12 & 20 & 6.5 \\
Semangko Timur-B & SS & $\sim 90$ & 35 & 20 & 6.9 \\
Semangko Graben & N** & 60 & 50 & 20 & 6.5 \\
Ujung Kulon A & SS & $\sim 90$ & 80 & 20 & 7.3 \\
Ujung Kulon B & SS & $\sim 90$ & 150 & 20 & 7.6 \\
Cimandiri & $\mathrm{R} * * *$ & E-W & 23 & 23 & 6.7 \\
Nyalindung-Cibeber & $\mathrm{R}$ & & 30 & 15 & 6.5 \\
Rajamandala & $\mathrm{SS}$ & & 45 & 22.5 & 6.6 \\
Lembang & $\mathrm{SS}$ & $\mathrm{E}-\mathrm{W}$ & 29.5 & 29.5 & 6.8 \\
Subang & $\mathrm{R}$ & $\mathrm{NW}$ & 33 & 16.5 & 6.6 \\
Cirebon-1 & $\mathrm{R}$ & $\mathrm{NW}$ & 15 & 7.5 & 6.5 \\
Cirebon-2 & $\mathrm{R}$ & $\mathrm{NW}$ & 18 & 9 & 6.5 \\
Karang Malang & $\mathrm{R}$ & $\mathrm{EW}$ & 22 & 22 & 6.7 \\
Brebes & $\mathrm{R}$ & & 22 & 11 & 6.5 \\
Tegal & $\mathrm{R}$ & $\mathrm{ENE}$ & 15 & 15 & 6.5 \\
Pekalongan & $\mathrm{R}$ & $\mathrm{NE}$ & 16 & 16 & 6.6 \\
Weleri & $\mathrm{R}$ & & 17 & 17 & 6.6 \\
Semarang & $\mathrm{R}$ & $\mathrm{EW}$ & 34 & 17 & 6.6 \\
Rawapening & $\mathrm{R}$ & $\mathrm{NW}$ & 18 & 9 & 6.5 \\
Demak & $\mathrm{R}$ & $\mathrm{EW}$ & 31 & 15.5 & 6.6 \\
Purwodadi & $\mathrm{R}$ & $\mathrm{EW}$ & 38 & 19 & 6.7 \\
Cepu & $\mathrm{R}$ & $\mathrm{ESE}$ & 100 & 50 & 7.1 \\
\hline & & & &
\end{tabular}

* Strike - Slip fault

** Normal fault

${ }^{* * *}$ Ring fault

period at several locations. Here UHS curves of sites $\mathrm{CPTu}-04, \mathrm{BH}-2$, and $\mathrm{CPTu}-13$ are presented in Figure 4, showing the maximum until the minimum values.

The CPTu-04 UHS curve shows the maximum value of spectral acceleration on $0 \mathrm{~s}$ period $(\mathrm{T})$, of $0.60 \mathrm{~g}$. The UHS curve's minimum value showed on CPTu-13, about $0.48 \mathrm{~g}$, while the UHS curve on $\mathrm{BH}-02$ showed the dominant UHS curve value in the Bandung Basin, which is $0.52 \mathrm{~g}$. These UHS curves were then further analysed using response spectra from deaggregation analysis to produce the Modified Response Spectra (MRS).

In the deaggregation stage, an analysis is carried out at the return period of 2475 years at the 0 second point (PGA). The results show that the dominant magnitude at the review locations: CPTu-04, BH -2, and CPTu-13 (Figure 5) is around 7.55-7.86 M, with a distance of about 66 $130 \mathrm{~km}$. The earthquake mechanism affecting the earthquake source and distance are shown in Figure 6. 
(a)

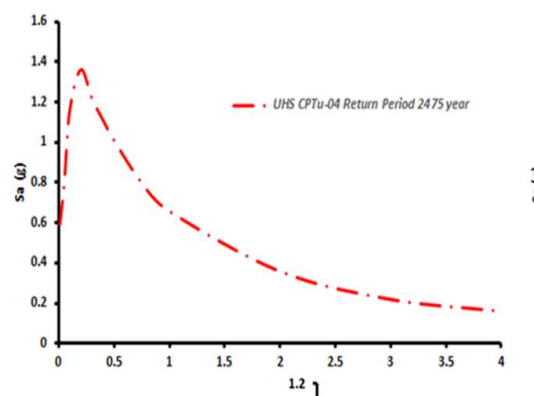

(b)

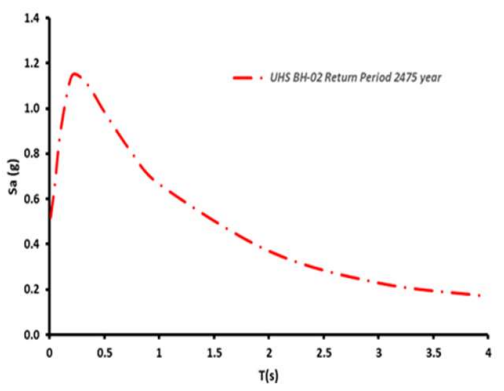

(c)

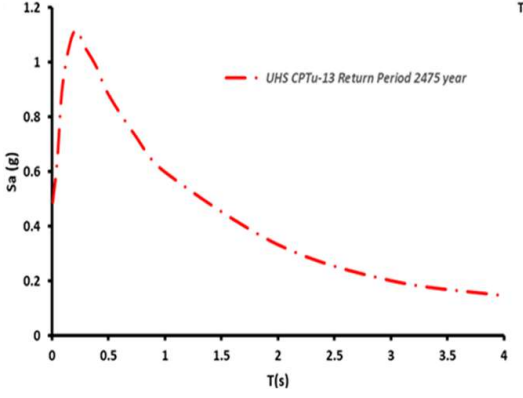

Figure 4. UHS curves in: (a) CPTu-04, (b) BH-02 and (c) CPTu-13.

(a)

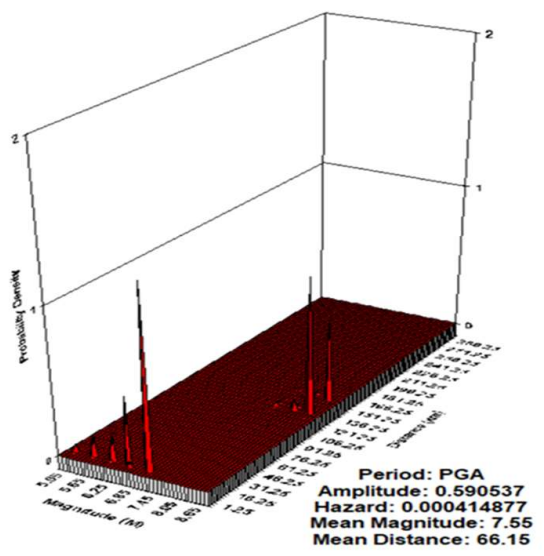

(b)

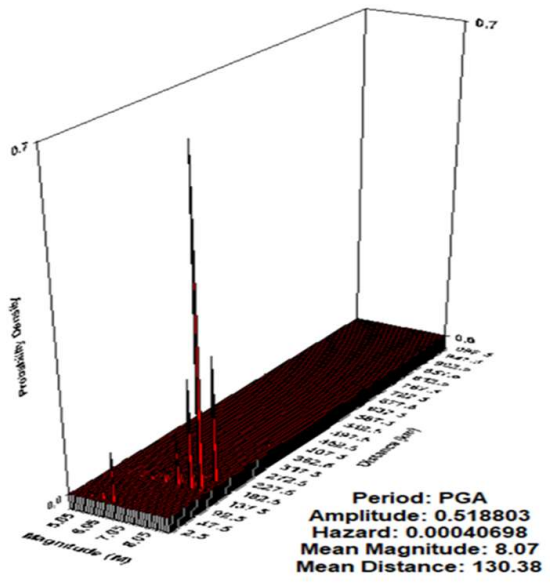

(c)

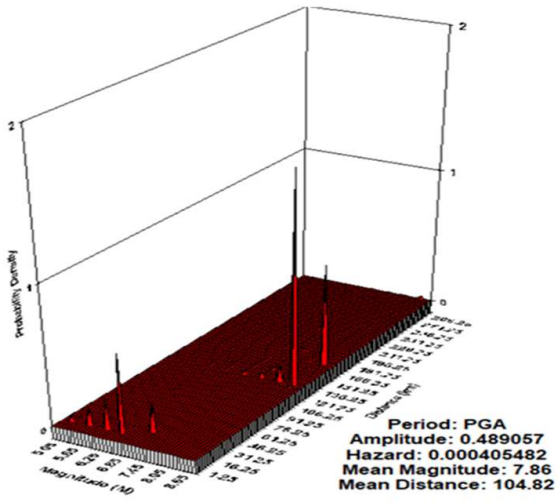

Figure 5. Deaggregation analysis results in: (a) CPTu-04, (b) BH-02 and (c) CPTu-13. 
(a)

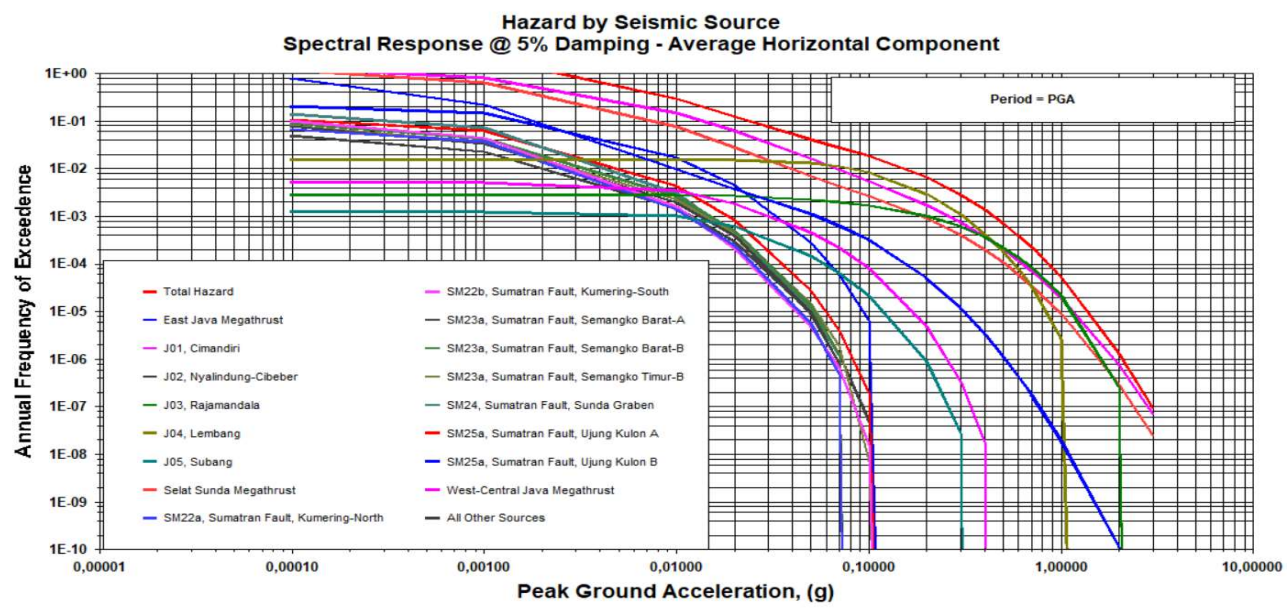

(b)

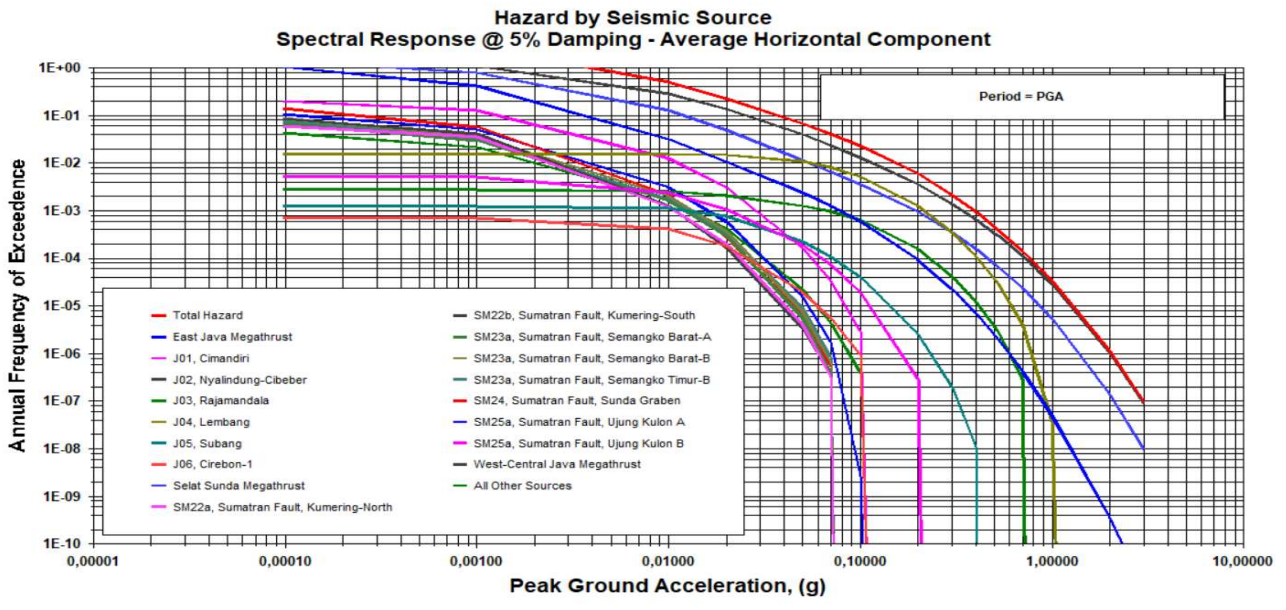

(c)

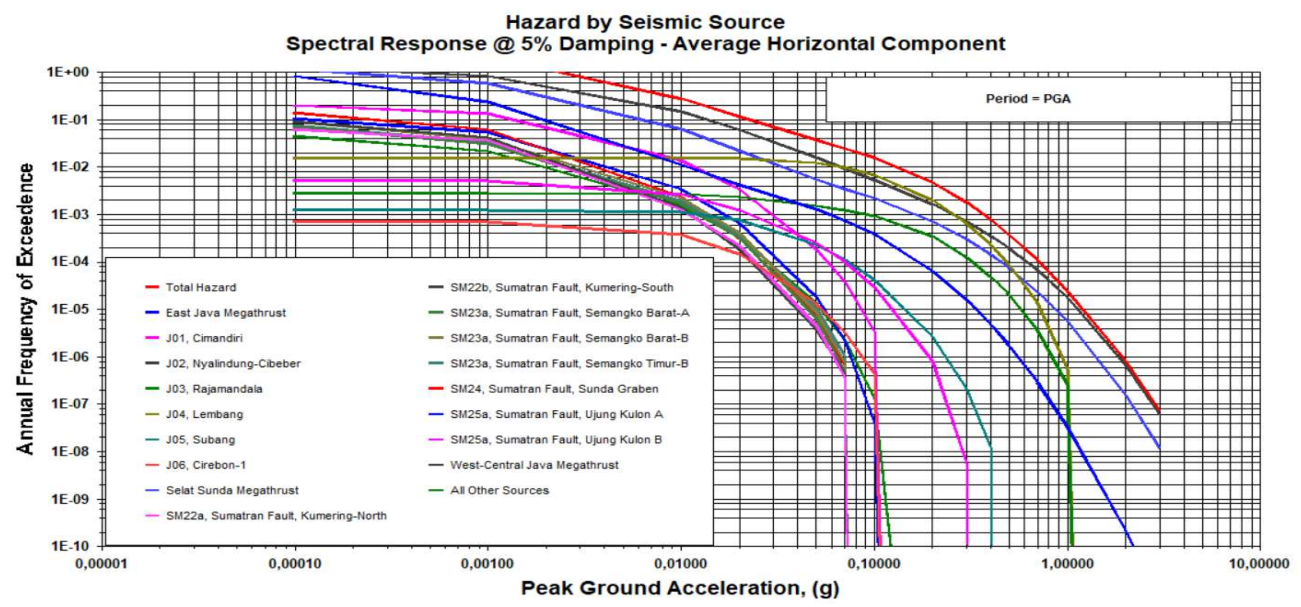

Figure 6. Seismic sources distribution graph in: (a) CPTu-04, (b) BH-02 and (c) CPTu-13. 
(a)

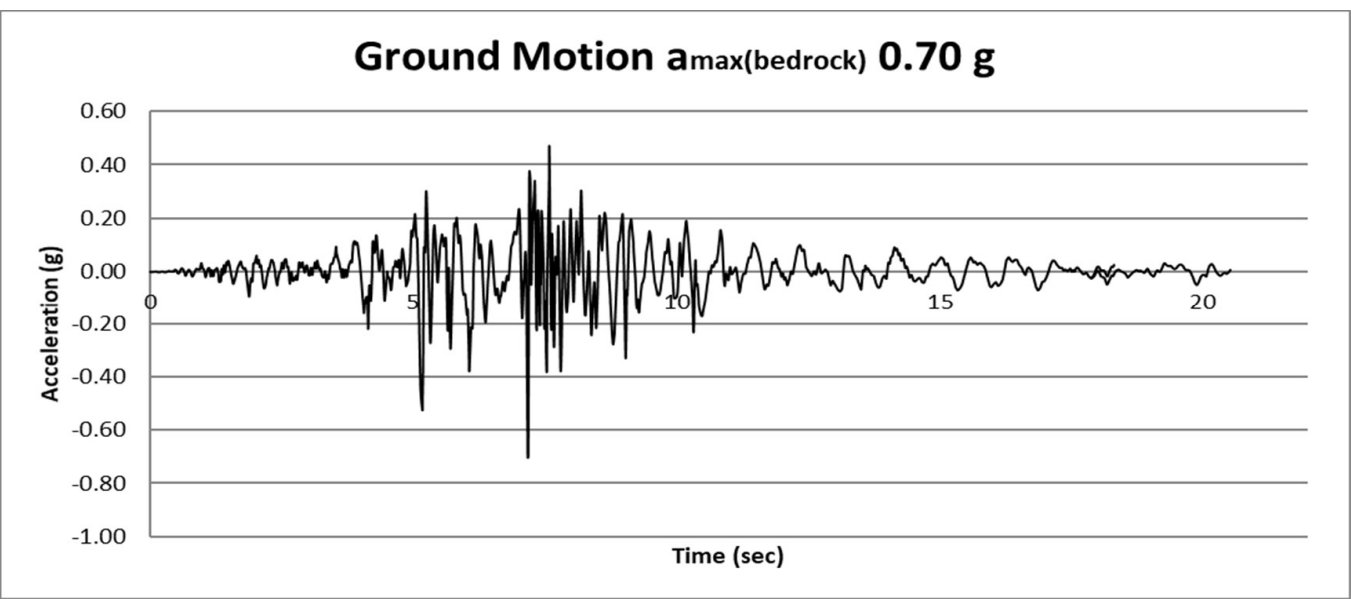

(b)

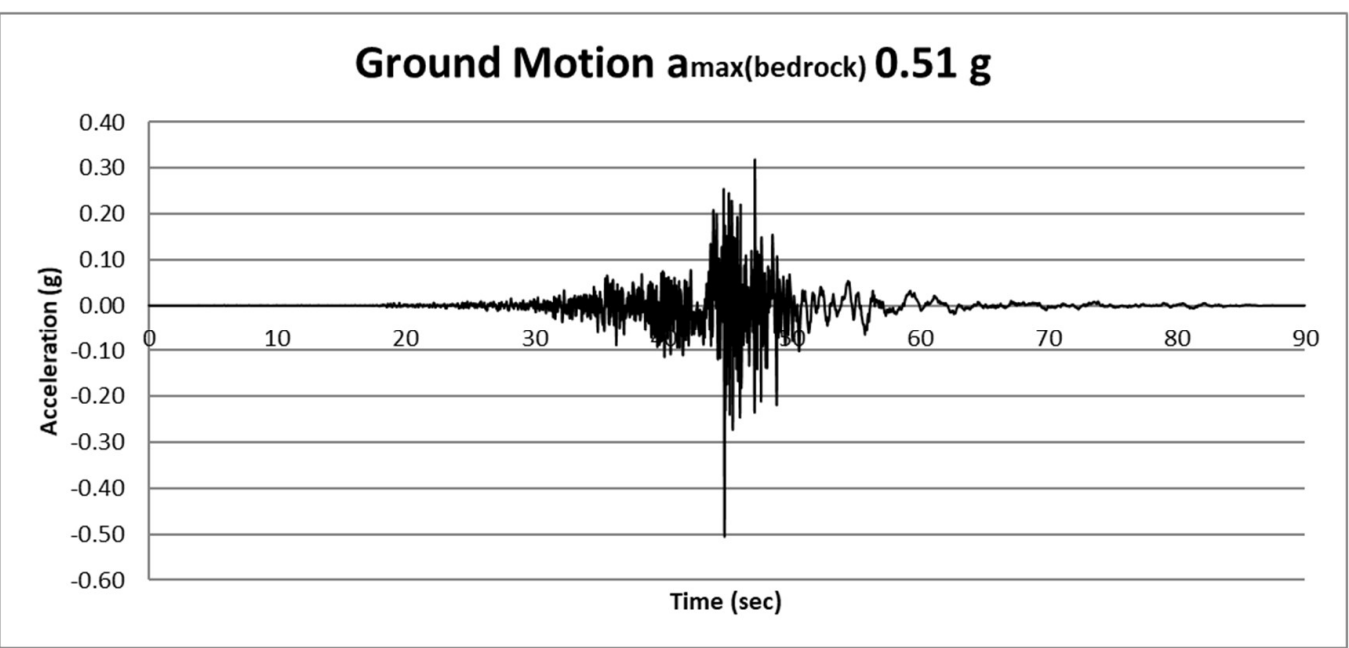

(c)

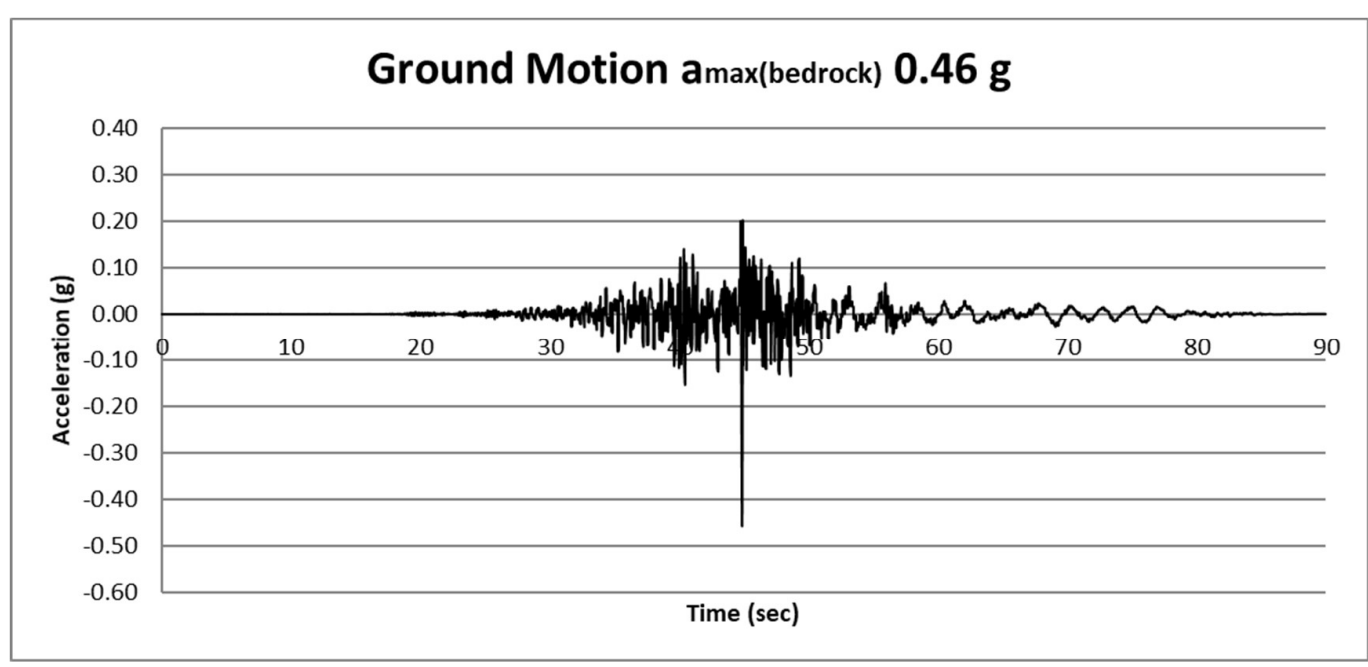

Figure 7. Ground motion synthetics in: (a) CPTu-04, (b) BH-02, and (c) CPTu-13. 
Table 3. PGA bedrock $\left(\mathrm{a}_{\max }\right)$ values for Bandung Basin.

\begin{tabular}{cccc}
\hline $\begin{array}{c}\text { SPT and CPTu } \\
\text { Locations }\end{array}$ & $\mathbf{a}_{\max }$ (bedrock), g & $\begin{array}{c}\text { SPT and CPTu } \\
\text { Locations }\end{array}$ & $\mathbf{a}_{\max }$ (bedrock), g \\
\hline BH01 & 0.502 & CPTu 01 & 0.578 \\
BH02 & 0.505 & CPTu 02 & 0.596 \\
BH03 & 0.488 & CPTu 03 & 0.518 \\
BH04 & 0.538 & CPTu 04 & 0.700 \\
BH05 & 0.486 & CPTu 05 & 0.517 \\
BH06 & 0.510 & CPTu 06 & 0.526 \\
BH07 & 0.538 & CPTu 07 & 0.509 \\
BH08 & 0.516 & CPTu 08 & 0.525 \\
BH10 & 0.497 & CPTu 09 & 0.506 \\
BH A & 0.488 & CPTu 10 & 0.543 \\
BH B & 0.492 & CPTu 11 & 0.677 \\
BH C & 0.488 & CPTu 12 & 0.668 \\
& & CPTu 13 & 0.457 \\
& & CPTu 14 & 0.505 \\
& & CPTu A & 0.621 \\
& & CPTu C & 0.506 \\
& & CPTu D & 0.481 \\
& & CPTu E & 0.483 \\
& & CPTu F & 0.486 \\
& & CPTu G & 0.500 \\
& & CPTu H & 0.532 \\
& & CPTu I & 0.497 \\
& & CPTu J & 0.512 \\
\hline
\end{tabular}

As shown in Figure 6, the seismic source distribution charts were observed to analyse the dominant seismic source's earthquake mechanism. The PGA values were plotted on the seismic source distribution graph against the hazard values. Then, we can observe the earthquake mechanism through the Annual Frequency of Exceedance. Experimental results toward 35 location points of $\mathrm{CPTu}-04, \mathrm{BH}-2$, and $\mathrm{CPTu}-13$ show that the subduction earthquake source mechanism has dramatically impacted the Lembang Fault at $\mathrm{CPTu}-04$ location points. Meanwhile, the earthquake source mechanism of the West-Central Java Megathrust has affected $\mathrm{BH}-02$ and $\mathrm{CPTu}-13$ location points.
The response spectra values were obtained from the deaggregation result using the dominant earthquake's magnitude and distance. It also considers the attenuation functions based on the earthquake source mechanism taken from the seismic source distribution graph.

To obtain the targeted response spectra, or better known as the MRS, the response spectra were modified using the UHS value. We performed spectral matching using the MRS and selected time histories to acquire the ground motion synthetic values on 35 sample points. The results of the ground motion synthetics analysis, as shown in Figure 7, show that soil acceleration in the bedrock varies from $0.46 \mathrm{~g}$ to $0.70 \mathrm{~g}$. The detailed 


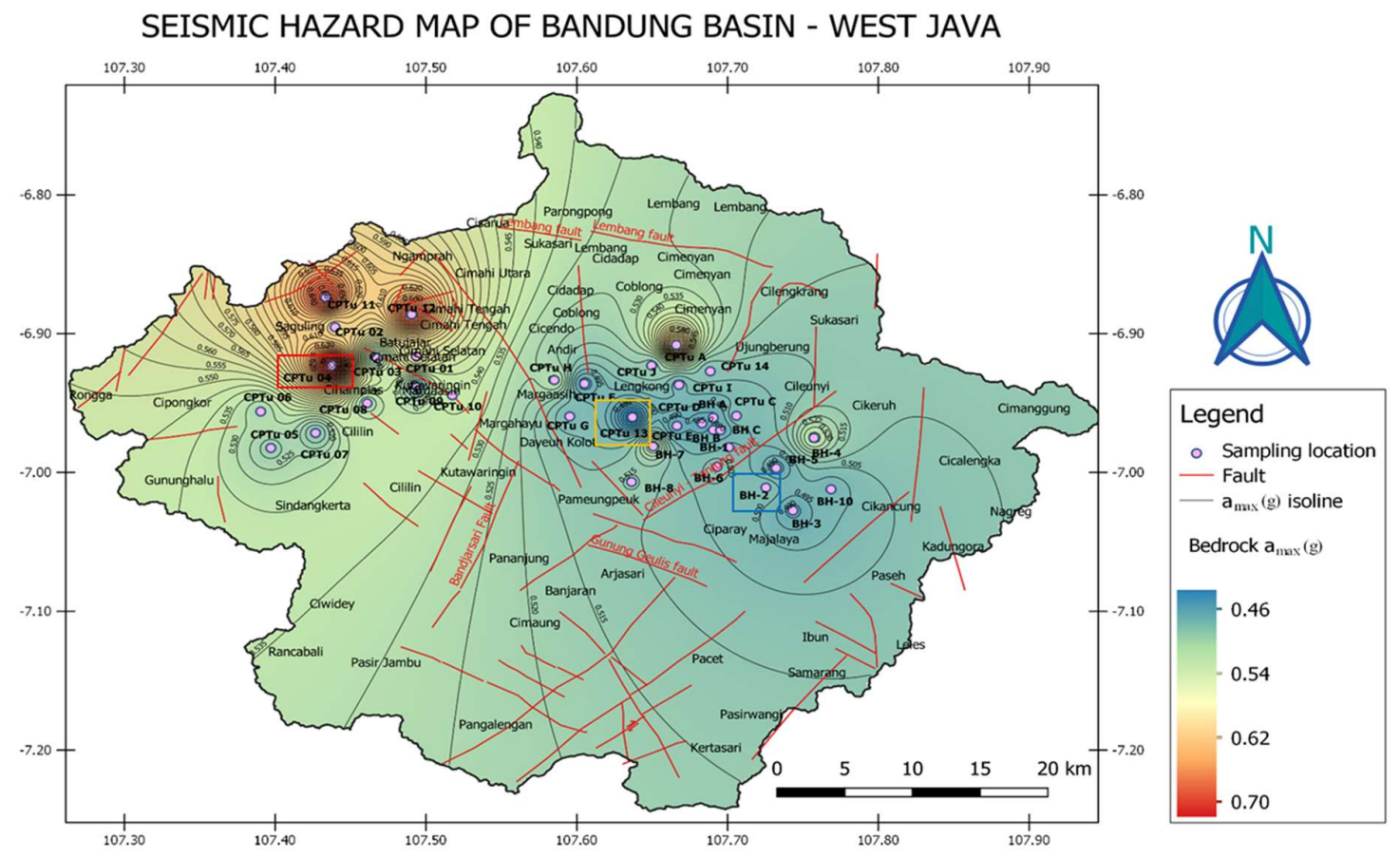

Figure 8. Seismic hazard map of the Bandung Basin. Red box, orange box and blue box show the location of CPTu04, CPTu13 and BH-02 respectively.

PGA values on the bedrock are presented in Table 3 .

The dominant earthquake magnitude and distance influence the variations of the PGA value. As we could see in Figure 8, the maximum value of $\mathrm{a}_{\max }$ showed in CPTu 04 is around $0.70 \mathrm{~g}$. This value is influenced by the Lembang Fault based on the deaggregation result. In contrast to $\mathrm{CPTu}-04$, the minimum PGA value showed in CPTu-13 is $0.46 \mathrm{~g}$, influenced by the West-Central Java Megathrust. Although these survey locations earthquake nearby, specific point locations can be more affected by different hypocentres and seismic sources. These results also showed that the needed seismic sources complete database are highly recommended to calculate more accurate seismic hazard analysis.

\section{CONCLUSION}

Our research results show that bedrock acceleration values in the Bandung Basin area range from $0.46 \mathrm{~g}-0.70 \mathrm{~g}$, while Indonesia Earthquake Map 2017 showed PGA values from $0.50 \mathrm{~g}-0.60 \mathrm{~g}$. This research shows more detailed results than previous research that would be advantageous for building construction references, such as designing bridges, tunnels, and tall buildings design construction. In the construction design calculation, it is crucial to give attention to an earthquake's acceleration load in the computation process. The discrepancy in the annual return period will affect the acceleration value in the bedrock. Apart from the differences, the number of seismic sources database will significantly affect the seismic hazard analysis results' accuracy.

\section{ACKNOWLEDGMENT}

The authors would like to extend our most profound appreciation to Ir. Eko Soebowo, Dr. Dwi Sarah, and Dr. Adrin Tohari for their supporting and valuable feedbacks during scientific paper writing. This research was supported by advanced institute seed grant programme of the International Science Council Regional Office for Asia and the Pacific (ISCROAP), the Integrated Research on Disaster Risk, International Centre of Excellence, Taipei (IRDR ICoE-Taipei) and 2020 National Innovation System Research project funding (INSINAS). 


\section{REFERENCES}

Alzwar, M., Akbar, N., Bachri, N., 1992. Peta geologi lembar Garut dan Pameungpeuk, Jawa: Geological map of the Garut dan Pameungpeuk quadrangle, Jawa, in: Peta Geologi Bersistem Indonesia. Pusat Penelitian dan Pengembangan Geologi, Bandung, pp. 1208-6, 1208-3.

Atkinson, G.M., Boore, D.M., 2003. Empirical ground-motion relations for subduction-zone earthquakes and their application to Cascadia and other regions. Bull. Seismol. Soc. Am. 93, 1703-1729. https://doi.org/10.1785/0120020156

Baker, J.W., 2013. White Paper: Introduction to Probabilistic Seismic Hazard Analysis.

Boore, D.M., Atkinson, G.M., 2008. Groundmotion prediction equations for the average horizontal component of PGA, PGV, and 5\%-damped PSA at spectral periods between $0.01 \mathrm{~s}$ and $10.0 \mathrm{~s}$. Earthq. Spectra 24, 99 138. https://doi.org/10.1193/1.2830434

Campbell, K.W., Bozorgnia, Y., 2008. NGA Ground Motion Model for the Geometric Mean Horizontal Component of PGA, PGV, PGD, and 5\% Damped Linear Elastic Response Spectra for Periods Ranging from 0.01 to $10 \mathrm{~s}$. Earthq. Spectra 24, 139-171. https://doi.org/10.1193/1.2857546

Chiou, B., Darragh, R., Gregor, N., Silva, W., 2008. NGA Project Strong-Motion Database. Earthq. Spectra 24, 23-44. https://doi.org/10.1193/1.2894831

Chiou, B.S.J., Youngs, R.R., 2008. An NGA model for the average horizontal component of peak ground motion and response spectra. Earthq. Spectra 24, 173-215. https://doi.org/10.1193/1.2894832

Daryono, M.R., Natawidjaja, D.H., Sapiie, B., Cummins, P., 2019. Earthquake Geology of the Lembang Fault, West Java, Indonesia. Tectonophysics 751, 180-191. https://doi.org/10.1016/j.tecto.2018.12.014

Daryono, Marfai, M.A., Ruslanjari, D., Winaryo, Purwaominta, A., 2009. Gempabumi Tasikmalaya Jawa Barat 2 September 2009. J. Kebencanaan Indones. 2, 595-606.

Gumilar, I., 2013. Pemetaan karakteristik penurunan muka tanah (land subsidence) berdasarkan integrasi metode GPS dan INSAR serta estimasi kerugian keekonomian akibat dampak penurunan muka tanah (Wilayah studi: Cekungan Bandung)[Doctoral Dissertation]. Institut Teknologi Bandung.

Gupta, I.D., 2002. The state of the art in seismic hazard analysis. ISET J. Earthq. Technol. 39, 311-346.

Hutasoit, L.M., 2009. Kondisi Permukaan Air Tanah dengan dan tanpa peresapan buatan di daerah Bandung: Hasil Simulasi Numerik. Indones. J. Geosci. 4, 177-188. https://doi.org/10.17014/IJOG.4.3.177-188

Koesoemadinata, R.P., Hartono, D., 1981. Stratigrafi dan sedimentasi daerah Bandung, in: Proceedings PIT X Ikatan Ahli Geologi Indonesia, Bandung. Ikatan Ahli Geologi Indonesia, Jakarta, pp. 318-336.

Krinitzsky, E.L., 2002. How to obtain earthquake ground motions for engineering design. Eng. Geol. 65, 1-16. https://doi.org/10.1016/S00137952(01)00098-9

Krinitzsky, E.L., 1995. Deterministic versus probabilistic seismic hazard analysis for critical structures. Eng. Geol. 40, 1-7. https://doi.org/10.1016/00137952(95)00031-3

Meilano, I., Abidin, H.Z., Andreas, H., Gumilar, I., Sarsito, D., Hanifa, R., Rino, Harjono, H., Kato, T., Kimata, F., Fukuda, Y., 2012. Slip Rate Estimation of the Lembang Fault West Java from Geodetic Observation. J. Disaster Res. 7, 12-18. https://doi.org/10.20965/jdr.2012.p0012

Sari, A.M., Fakhrurrozi, A., Syahbana, A.J., 2020. Peak Ground Acceleration on Bedrock using Probability Seismic Hazard Analysis Methods in Bandung City, in: Proceedings of the Proceedings of the 7th Mathematics, Science, and Computer Science Education International Seminar, MSCEIS 2019, October 12th, 2019, Bandung, West Java, Indonesia. EAI. https://doi.org/10.4108/eai.12-102019.2296498

Sari, A.M., Soebowo, E., Fakhrurrozi, A., 
Syahbana, A.J., Tohari, A., 2019. Microzonation of Soil Amplification Based on Microtremor, Spt, and Cptu Data in Bandung Basin. Ris. Geol. dan Pertamb. 29, 53.

https://doi.org/10.14203/risetgeotam2019.v 29.978

Sengara, I.W., Munaf, Y., Susila, I., 2001. Seismic Risk and Site Response Analysis for City of Bandung-Indonesia. Int. Conf. Recent Adv. Geotech. Earthq. Eng. Soil Dyn. 1-6.

Silitonga, P.., 2003. Peta geologi lembar Bandung, Jawa: Geological map of the Bandung quadrangle, Jawa, in: Peta Geologi Bersistem Indonesia. Pusat Penelitian dan Pengembangan Geologi, Bandung.

Soehaimi, A., 2011. Seismotektonik Jawa Barat dan Mikrozonasi Potensi Bencana Gempa Bumi DKI Jakarta. Badan Geologi Kenmenterian ESDM, Bandung.

Sudjatmiko, 2003. Peta Geologi Lembar Cianjur, Jawa: Geological Map of the Cianjur Quadrangle, Jawa, in: Peta Geologi Bersistem Indonesia. Pusat Penelitian dan Pengembangan Geologi, Bandung.

Sunardi, B., 2015. Percepatan Tanah Sintetis Kota Yogyakarta Berdasarkan Deagregasi Bahaya Gempa 6, 211-228.

Supendi, P., Nugraha, A.D., Puspito, N.T., Widiyantoro, S., Daryono, D., 2018. Identification of active faults in West Java, Indonesia, based on earthquake hypocenter determination, relocation, and focal mechanism analysis. Geosci. Lett. 5, 31. https://doi.org/10.1186/s40562-018-0130-y
Syahbana, A.J., Sari, A.M., Soebowo, E., Irsyam, M., Asrurifak, M., Hendriyawan, 2018. Analysis of Bedrock Synthetic Ground Motion on Bandung City using PSHA Method, in: Proceedings 20th Southeast Asian Geotechnical Conference 3rd AGSSEA Conference In Conjunction with 22th HATTI Annual Scientific Meeting Thema Geotechnical Challenge for Mega Infrastructures. Indonesian Society for Geotechnical Engineering, Jakarta, pp. 290295.

Tim Pusat Studi Gempa Nasional, 2017. Peta Sumber dan Bahaya Gempa Indonesia Tahun 2017.

West Java Province Metropolitan Development Management (WJPMDM), 2013. Konsep Awal Pengembangan Metropolitan Bandung Raya, WJP-MDM - Mei 2013. Bandung.

Youngs, R.R., Chiou, S.J., Silva, W.J., Humphrey, J.R., 1997. Strong ground motion attenuation relationships for subduction zone earthquakes. Seismol. Res. Lett. 68, 58-73. https://doi.org/10.1785/gssrl.68.1.58

Yulianto, E., 2011. Understanding the Earthquake Threat to Bandung from the Lembang fault. Jakarta.

Zhao, J.X., Zhang, J., Asano, A., Ohno, Y., Oouchi, T., Takahashi, T., Ogawa, H., Irikura, K., Thio, H.K., Somerville, P.G., Fukushima, Yasuhiro, Fukushima, Yoshimitsu, 2006. Attenuation relations of strong ground motion in Japan using site classification based on predominant period. Bull. Seismol. Soc. Am. 96, 898-913. https://doi.org/10.1785/0120050122 
Sari and Fakhrurrozi: Seismic Hazard Microzonation Using Probability Seismic Hazard Analysis on Bandung Basin 